\title{
Computational thinking using ICT in Chemical education: a research record in Amazonas/Brazil Region
}

Pensamento computacional utilizando TIC na educação Química: um registro de pesquisa nas Amazonas / Região do Brasil

Pensamiento computacional utilizando las TIC en la educación Química: un registro de investigación en la región Amazonas / Brasil

Eleonora Celli Carioca Arenare ORCID: https://orcid.org/0000-0002-6586-6257

Universidade Federal Fluminense, Brazil

E-mail: eleonoracelliquimica@gmail.com

\begin{abstract}
The research records of the last decade bring a systemic look, which involves historicity and triggers strategies with perspectives to solve problems and dilemmas that involve the educational context. The article addresses the difficulties that teachers have in integrating ICT as a motivating tool for the problem of the lack of interest of students in chemistry classes. The observation was made with chemistry teachers from thirteen public schools in the city of Manaus in the Midwest Zone, the State Department of Education of Amazonas - SEDUC. The results obtained through the questionnaires applied were tabulated and analyzed using the Likert scale, demonstrating how insufficient this integration is. The implications of this research address the difficulties that need to be overcome in relation to the computational thinking of chemistry teachers, bringing perspectives on the need for continuing education courses for professionals involved with this science.
\end{abstract}

Keywords: Computational thinking; Chemistry teaching; Information and Communication Technologies - ICTs.

\section{Resumo}

Os registros de pesquisas da última década trazem uma perspectiva sistêmica, que envolve a historicidade e dispara estratégias com perspectivas para resolver problemas e dilemas que envolvem o contexto educacional. O artigo aborda as dificuldades que os professores têm para integrar as TIC como ferramenta motivadora para o problema do desinteresse dos alunos pelas aulas de química. A observação foi realizada com professores de química de treze escolas públicas da cidade de Manaus na Zona Centro-Oeste, Secretaria de Educação do Estado do Amazonas SEDUC. Os resultados obtidos por meio dos questionários aplicados foram tabulados e analisados por meio da escala Likert, demonstrando o quão insuficiente é essa integração. As implicações desta pesquisa abordam as dificuldades que devem ser superadas em relação ao pensamento computacional dos professores de química, fornecendo perspectivas sobre a necessidade de cursos de formação continuada para os profissionais envolvidos com esta ciência. Palavras-chave: Pensamento computacional; Ensino de Química; Tecnologias de Informação e Comunicação - TIC.

\section{Resumen}

Los registros de investigación de la última década traen una mirada sistémica, que involucra historicidad y desencadena estrategias con perspectivas para resolver problemas y dilemas que involucran el contexto educativo. El artículo aborda las dificultades que tienen los profesores para integrar las TIC como herramienta motivadora para el problema del desinterés de los estudiantes por las clases de química. La observación se realizó con profesores de química de trece escuelas públicas de la ciudad de Manaus en la Zona Medio Oeste, Departamento de Educación del Estado de Amazonas - SEDUC. Los resultados obtenidos a través de los cuestionarios aplicados fueron tabulados y analizados mediante la escala Likert, demostrando lo insuficiente que es esta integración. Las implicaciones de esta investigación abordan las dificultades que deben superarse en relación con el pensamiento computacional de los profesores de química, aportando perspectivas sobre la necesidad de cursos de educación continua para los profesionales involucrados en esta ciencia.

Palabras clave: Pensamiento computacional; Enseñanza de la Química; Tecnologías de la Información y la Comunicación - TIC. 


\section{Introduction}

Chemistry is a science that studies the elements that constitute nature and the substances that can form, emphasizing their characteristics, combinations, acquisition processes, applications and identification. Study how these elements will be able to react to each other, from their properties, seeking an understanding for the forms of connections they can exert with other elements, as well as the energy released or absorbed during these transformations. In the current educational process, it is necessary to discuss with students in the classroom the social function of chemical knowledge and the meaning of this science in being part of the school curriculum.

The high number of failures in the disciplines of the area of exact sciences, particularly in high school, indicates a high degree of difficulty in these students in learning scientific concepts. Several factors can generate this situation: the lack of capacity that students have in the interpretation of reading, whether problems or texts, the lack of a solid mathematical basis, are among the problems that most interfere in the learning of chemistry, because most students can not understand the affirmation of problems and have difficulty triggering a logic of solution by little understanding of how to use mathematical calculus.

In the student motivation process, it is difficult to accept the need to include the curricular component of Chemistry, without being convinced that you are studying something important that you will not get lost throughout your life by not having a practical use for your day to day or for your life in the future. With the remarkable advances in electronic technology in recent years and innovations in less and less time, the act of teaching classes as it was done at the end of the 20th century is doomed to failure. How to expect a student who, when he comes home, computer, internet and many other modern electronic equipment, even those from less favored families, to motivate themselves with classes without using the same technology that is part of their daily life? It is evident that teachers, from any area, urgently need to modify teaching methodologies and strategies, highlighting the understanding of the reasons and objectives that justify and motivate their classes.

What is needed is "education for decision-making, social and political responsibility. An education that would allow men to bravely discuss their problems. Education that would put him in constant dialogue with each other. Identify with scientific methods and processes" (Freire, 1996). This education is done using methodologies that explore memorization and this value calculation, but with procedures that develop the capacity for reflection, research and entrepreneurial action.

Inserted in the Amazon, we understand that it is necessary to involve the Teaching of Chemistry with the reality of our students, highlighting the richness of the forest and the substances that can be extracted from plants, in addition to conserving natural resources and many other themes that this environmental region offers us.

The initial training (diploma) in Chemistry is deficient, as it does not establish a relationship between the course and reality. The current issues of society and the creation of methodologies and strategies for the teaching of chemistry are in the background to the detriment of the study of "pure chemistry", apparently training more researchers than teachers.

The view of the teacher who sees the formation of the citizen included in his environment is impaired, since he himself does not have this formation, which discourages the student and disconnects him from reality. The teacher needs to work on the reconstruction of knowledge, involving research and teaching in an inseparable way, so that he can reframe the Teaching of Chemistry.

Reading the past makes you understand that, at all times, technologies have always been a social highlight. At each station, there was always a certain technology that was used by the educational community. Chalk, the blackboard, the newspaper, textbooks, the magnetic picture, although they are outdated technologies, even today, when well used in the educational context, can undoubtedly favor learning and contribute significantly to the teaching-learning process. 
By integrating information and communication technologies (ICT) with teaching chemistry, greater efficiency in learning this discipline is expected. For this to happen it is necessary the training and pedagogical preparation of teachers. According to Paulo Freire (1996), "one should not be naïve in relation to technology, even if there is enormous potential to stimulate and challenge the curiosity of children and adolescents, there is much to be done to transform it into a tool of social inclusion and development of citizenship in a definitive political-pedagogical project of the school".

Information and Communication Technologies (ICT) integrated into Chemistry Teaching will provide surprising results, as stated above, most adolescents and young people have been influenced by resources that technology provides today, such as television, computer, Internet, game software, videos, CD-ROM, hypermedia, tools such as Chat, groups or mailing list, forum, teleconference, email and other audiovisual languages, which can collaborate significantly to make the process more efficient and effective.

Within this perspective, the problem is: will chemistry teachers from public schools in Manaus be prepared for the integration of ICT in chemistry teaching, in order to contribute to the improvement of the teaching-learning process amid the difficulties that schools present in Manaus?

This article is part of a Dissertation defended in a public institution in the Northern Region, has as general objective: To disseminate the record of computational thinking of chemistry teachers in the past decade from the integration of Information and Communication Technologies (ICT) in the Teaching of Chemistry in public schools of Manaus / Amazonas / Brazil.

To develop this research and establish answers to the problem, we have established the following specific objectives: 1-Distinguishing how high school chemistry teachers obtained knowledge of Information and Communication Technologies (ICT), as a possibility to diversify the teaching of this Science; 2- Diagnose the use of Information and Communication Technologies (ICT) in high school chemistry classes in state schools belonging to the Midwest Zone of the city of Manaus; 3- To know the training in Information and Communication Technologies (ICT), of teachers who teach Chemistry in the state school network of Manaus; 4-Identify the conceptions of chemistry teachers regarding the use of ICT in their classes.

The relevance of the article is justified by the record that highlights how the difficulties that chemistry teachers have to integrate as ICT as a motivation tool or problem of lack of interest of students in their chemistry classes, taught for high school.

\subsection{Information and Communication Technologies and Current Education}

In the midst of the undeniable presence of technologies in human life, we understand that the school, as an educational institution, cannot ignore this teaching- learning process. In this sense, many authors (Fofonca, 2009; Chiapinoto, 2010; Dante, 2004; Rabbi, 2009; Bottentuit Junior, 2009) has researched and published on this topic, explaining the significant contributions that ICT can promote the educational process.

These transformations intervene in the various spheres of life, causing economic, social, political and cultural changes, also affecting the school and the professional practice of teaching. Faced with this new demand, the school needs to be rethought, ceasing to be merely an agency that transmits information and become a place of critical analysis and information production (Santana, 2009).

Research conducted by the Internet Steering Committee in Brazil in 2009 regarding the use of Information and Communication Technologies, through CETIC1, shows that the ownership of computers and the Internet has grown in 
Brazilian households. With the increase in purchasing power and the ease of credit, the acquisition of computers as well as the use of the Internet has grown rapidly in Brazil, following the global trend in the richest countries.

Figure 1 shows the growth of computer ownership and internet use in Brazil. The data show an increase in the acquisition of computers for households in the temporal state from 2014 to 2018. Exactly households that had no internet or computer, had an increase of $12 \%$ in the period from 2014 to 2018, an increase of $12 \%$ in the number of households with internet and computer.

This growth means that this information and communication technology tool, which has invaded Brazilian homes and is already part of the reality of most students, cannot be neglected by those who work in education. In fact, with regard to the Brazilian educational context: Kennisnet (2015) shows through its scheme that technical and human elements directly interfere in the use of ICT in the classroom.

Figure 1 - Growth of computer ownership and internet use in Brazil.

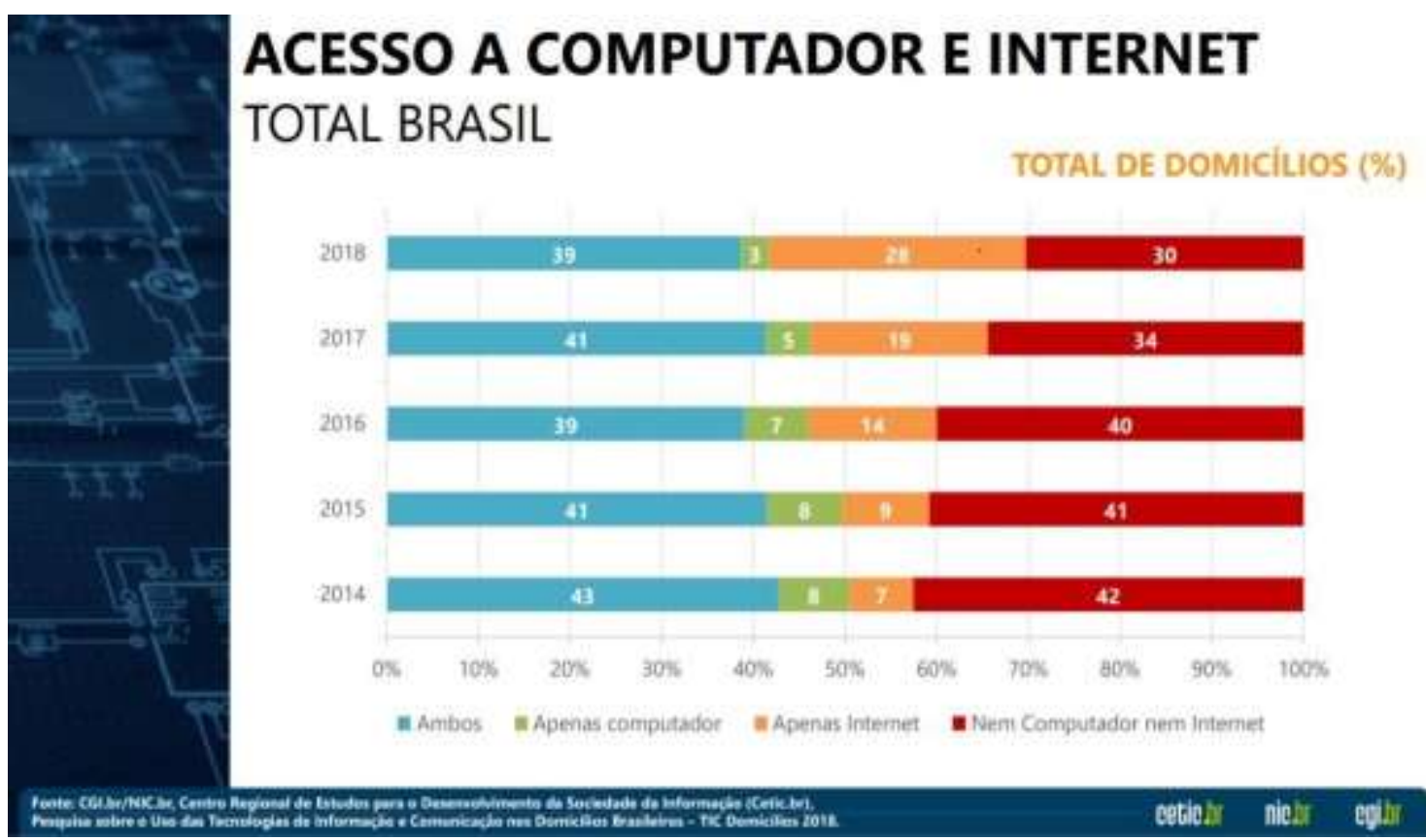

Source: CGI.br/NIC.br, Regional Center for Studies for the Development of the Information Society (Cetic.br), Research on the Use of Information and Communication Technologies in Brazilian Households - ICT Households (2018).

The results are significant to express the interest and motivation of the use of new technological resources. The presence of the computer in the residences can be used by teachers as a facilitating resource to promote the integration of ICT in the teaching- learning process, since, with the computer at home, the student is more likely to investigate subjects addressed in the classroom, seeking to better understand the importance of the contents of their disciplines, aggregating information. 


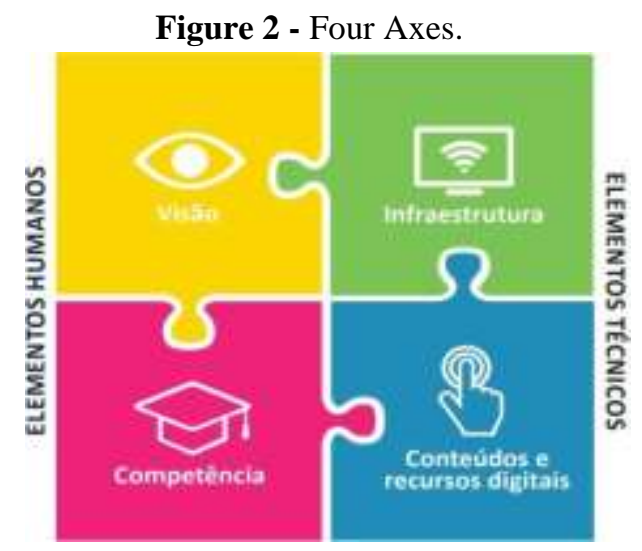

Fonte: Kennisnet (2015).

According to the Kennisnet model (2015), as shown in Figure 2, the four axes must be in balance so that the use is effective, oriented and controlled. To do this, it is up to the government to ensure that the school has the information that students need, create conditions for them to have projects appropriate to their reality and can structure teaching and learning processes more efficiently and improving the transparency of activities for parents and society.

The integration of ICTs into the teaching-learning process, in order to improve scientific education, has been the object of study by several researchers. In the region Some researchers highlight the importance of teacher education in the contextualized Amazon, since it needs to build scientific knowledge and not just transmit it. Encourage the student in this construction, which needs to be dialectical and creative and able to collaborate significantly for the society in which it operates. From this perspective, it is understood that the knowledge described or passed on by someone becomes only information, since the computer stores information and not knowledge. (Trevisan, 2008; Da silva, 2009; Menezes, 2009).

For the construction of knowledge, in a competitive world, up-to-date agile information is essential and in developing countries, it is not always quickly socialized in the educational context. The lack of infrastructure, especially fast connections and even its absence in isolated communities, have hindered the dissemination of scientific knowledge, especially in relation to Chemistry in the Amazon region with all the potential and attractions it can provide.

Understanding school education is a democratic communication process, which presupposes the participation of subjects from their sociocultural context, becoming a space of socialization between subjects and socialization of the knowledge generated by the subjects; to know that, when shared with others, they play their broader role, which is to contribute to the student's construction and rebuilding, opening and appropriating his world (Gutiérrez, 2003). Thalamus (2004, p.2) recognizes that there is a need to "feed" the individual through information, Thalamus (2004, p.2) recognizes that there is a a need to "feed" the individual through information, within the Information Society:

Information is always flowing and for the subject works as an exchange with the outside world, which gives it its social character. (...) In contemporary society, actors need knowledge not only to survive, but also to do it in the best possible way. Only the subject can generate it, which means that knowledge is a human action.

Miranda (2007) highlights the elements necessary for the construction of significant knowledge, which are obviously independent of the technology used:

(...) students build new knowledge based on structures and representations already acquired about the phenomena under study and that must be cognitively and emotionally involved in the processing of new information. 


\subsection{Information and Communication Technologies and Chemistry Teaching}

The use of ICT in the teaching of chemistry has followed human history since the beginning considering the idea of technology as all the tools used in the development of science. The association of ICTs with the use of computers is and the first reference to the use by chemistry teachers took place in 1959 in the United States and was intended for academic research. Only in 1969 at the University of Texas was a simulation created for use in chemistry classes.

In the 1970s and 1980s, computers decreased in size, became popular and, consequently, allowed greater integration of the various areas of knowledge. Characterized by the use of multimedia and Windows, the 1990s allowed greater interaction between the user and the computer.

The popularization of the use of computers and the emergence of the global internet network have allowed a wide interaction of the entire scientific community, also benefiting from the exchange of information on chemistry and its most recent advances.

Teaching chemistry requires the teacher a willingness to innovate in his classes, seeking to reflect a desire to integrate his students into social life, which requires a constant updating of this professional.

Integrating ICTs into the teaching and learning process requires research, skill and competence. Many researchers have understood and affirmed that this static situation developed within the educational system is closely linked to the teacher's education and competence.

"The uses of differentiated digital technologies, for example, in face-to-face courses, require new skills of teachers, strategies and diversified dynamics to present their classes. Much changes since the presentation and organization of content, performance of activities, distribution of time, definition of the forms of participation of teachers and students and the evaluation process" (Maia \& Meirelles, 2009)

According to Perrenoud (2000), competence is "an ability to act effectively in a certain type of situation, supported by knowledge, but without limiting itself to them", which demonstrates the need for a theoretical deepening of the teacher, because if the one who acts effectively in a situation is competent, it will be in the same proportion as having mastery of the knowledge that supports this action.

Like any professional activity today, the teacher cannot limit himself to reproducing the same knowledge acquired when he was a student. You need a constant update, continuous training throughout your career.

The challenge is to formulate and propose didactic sequences that serve, simultaneously, for the teacher's learning process and as a possible suggestion of teaching process that he can develop with his students. Activities that, by escaping from the model of reproduction and transmission of content, promote the significant learning of the teacher, both of the conceptual issues involved and of the teaching methodology employed. (Trivelato, 2003).

Freire, (1996) points out that continuing education is important to maintain motivation in the classroom. The teacher must be a current man and not lose the dreams of a redemptive education. If the system does not modify education, then education should modify the system with small changes and short steps, but a walk that keeps the teacher alive, because true death is in inertia.

The soul of any educational institution is the teacher. As much as one invests in equipping schools, laboratories, libraries, amphitheaters, sports courts, swimming pools, soccer fields without denying the importance of all this instrumental - all this is not more than material aspects compared to the role and importance of the teacher (Chalita, 2001). 
The process of continuing education for chemistry teachers brings the possibility to instigate in these the desire to improve their teaching methodologies and strategies, highlighting and demonstrating the numerous possibilities that ICTs provide to Chemistry Teaching, giving it the possibility to become creators of scientific technological resources, such as teaching methodologies, teaching strategies, videos, websites, blogs, projects, hypertext, software hypertexts, etc.

Continuing education should have as a priority to involve the teacher in the chemical world, through theoretical argumentation that enables him not only an object of work, but make him a participatory agent of the process, not fearing errors, but learning to live with them and overcome them, through dedication, research and scientific research, being able to exercise the ability to expose their ideas, without fearing the divergence of opinions, assuming that the school, or the university is a space where differences are freely expressed (Garcia, 2004).

Chemistry teachers need to seek professional refresher courses, participate in research projects, and publish their work. In this way they will perceive the applications of what they study, where they approach the problems and issues that may most intrigue them, this is a window to a process of internal motivation of students. Thus, teachers and students will be more motivated for a teaching-learning process, where modern technologies are used and innovative experiences are realized.

Educating ourselves and educating others for the information society is a challenge, which we chemistry teachers have to overcome, since our own training has not been satisfactory in relation to certain situations that we experience in our society. In this perspective, continuing education should point out ways for the integration of ICTs to the process of teaching-learning chemistry, enabling the teacher to approach what the student experiences outside the school. It is not a question of making the teacher an expert in Informatics, but to enable him to appropriate the use of technologies, in order to maximize the teaching-learning process in Chemistry.

\section{Methodology}

Research has an intentionality, which consists in elaborating a set of knowledge that makes it possible to understand and transform reality.

The methodology is a set of procedures and techniques used in the investigation process, including related aspects of how to do the research. It can also be said that the methodology is related to the ideological posture of the researcher, with its objectives and assumptions (Inácio Filho, 2004 p.71).

\subsection{Characterizing the Research Context}

The development of this work consists of bibliographical research, realization of the state of the art through articles, dissertations and theses updated and field research. With quantitative approach, as a current of thought the historical dialectical materialism, through a participatory action research, developed to obtain information about the integration of information and communication technologies in the teaching-learning process in chemistry in public schools of Manaus, being an empirical investigation that presupposes a field research, with the purpose of data analysis.

The extension of the research field was limited, focusing on teachers who teach in high school the chemical discipline, belonging to the District Coordination III. 


\subsection{Information Collection Tools}

The questionnaire was based on the objectives of the research, covering situations related to the characterization of the research subjects, level of teacher education regarding the use of ICTs to teach chemistry, teachers' conceptions regarding ICTs for the teaching-learning process in chemistry and an investigation on the need for continuing training courses in the investigated process.

The questionnaire was based on the objectives of the research, covering situations related to the characterization of the research subjects, level of teacher education regarding the use of ICTs to teach chemistry, teachers' conceptions regarding ICTs for the teaching-learning process in Chemistry. We chose to use a questionnaire (closed questions), based on the Likert scale.

The Likert scale, in honor of its creator Rensis Likert, is a classification scale that requires respondents to indicate the degree of agreement with each of the statements presented. Among the advantages sought from the Likert scale are: a) it is a scale of easy construction and application; b) uses statements that are not explicitly linked to the attitude studied, allowing the inclusion of any item that is empirically verified; c) it is consistent with the final result, in addition to the fact that the interviewees quickly understand how to use the scale; d) presents facilities, since it is offered by the Internet dispensing with the presence of researchers in the application (Mattar,2001).

Each response cell is assigned a number that reflects the direction of the respondent's attitude towards each statement/information. The total score of the attitude of each respondent is given by the sum of the scores obtained for eachstatement. Two questionnaires were elaborated that followed the planning specified in Table 1.

Table 1 - Statement of the planning of Questionnaires 1 and 2.

\begin{tabular}{|c|c|c|}
\hline QUESTIONÁRIO & OBJETIVOS & PERGUNTAS \\
\hline 1 & Caracterizar dados gerais dos professores & $\begin{array}{l}\text { Sexo, idade, ano de conclusão da } \\
\text { graduação, tipo de instituição, } \\
\text { habilitação, experiência docente, } \\
\text { utilização das TICs na } \\
\text { graduação. }\end{array}$ \\
\hline $\begin{array}{c}2 \text { (Quadros } \\
01,02,03,04,05)\end{array}$ & $\begin{array}{l}\text { Identificar o nível de formação do } \\
\text { professor em TICs para ensinar química } \\
\text { Diagnosticar a integração das TICs no } \\
\text { ensino de química em escolas públicas de } \\
\text { Manaus }\end{array}$ & $\begin{array}{l}\text { Posse de equipamentos } \\
\text { tecnológicos e sua utilização em } \\
\text { sala de aula, englobando TICs } \\
\text { no ensino de química, recursos } \\
\text { tecnológicos e sua utilização nas } \\
\text { aulas de Química, desafios a } \\
\text { serem superados neste contexto. }\end{array}$ \\
\hline
\end{tabular}

Source: Own authorship.

The two questionnaires were divided into two blocks, containing open and closed questions. Questionnaire 1 requests the general data of the individual, his/her education and relationship with the technologies (year of graduation, type of institution, qualification, teaching experience, use of ICTs in this training) (Table 2). 
Table 2 - Questions regarding Questionnaire 1 Vraelys 1.

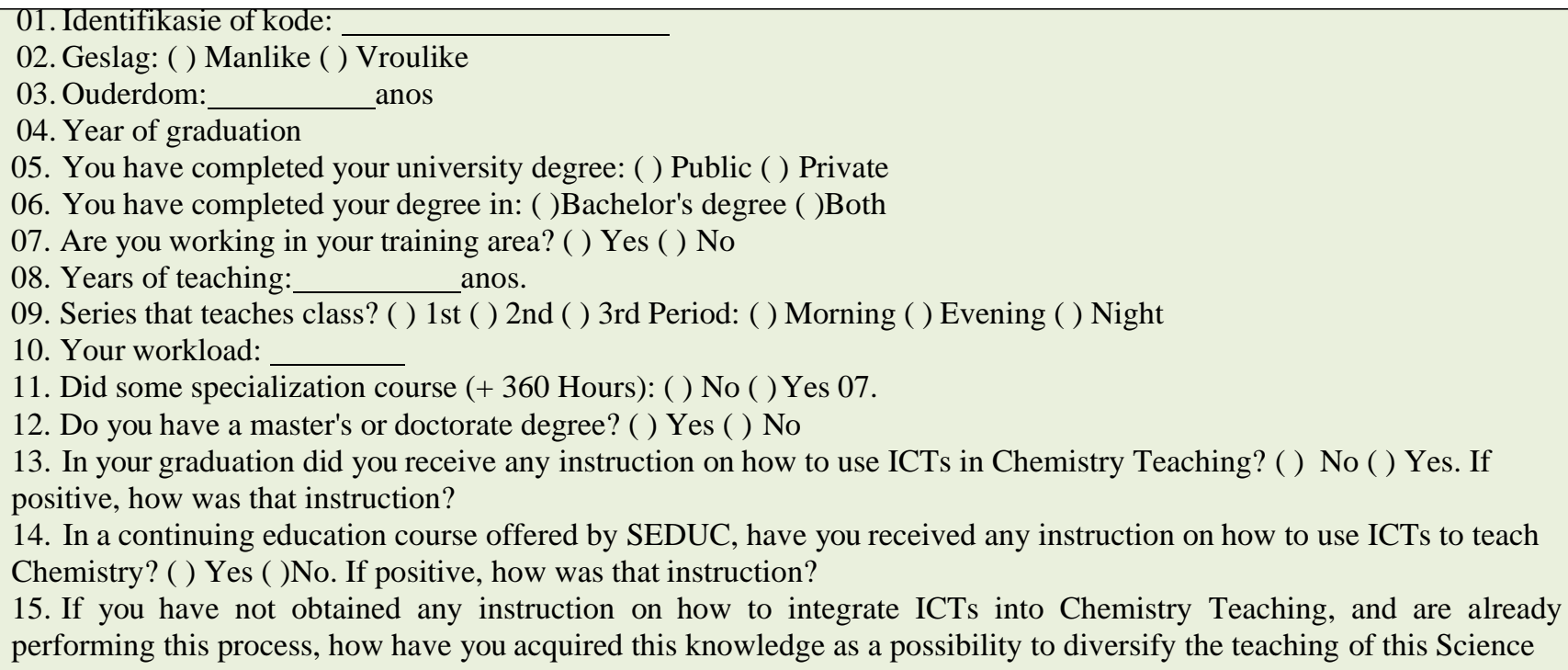

Source: Own authorship.

Questionnaire 2, divided into 5 categories, aims to trace the teacher's perception of the integration of ICTs in the process of teaching and learning chemistry, investigating factors that have collaborated or not so that this integration is a reality in public schools in Manaus, seeking to know the level of knowledge of the teacher as the ICTs in chemistry teaching and the need for a continuing education course that addresses this theme

Questionnaire 2 - Using or not Information and Communication Technologies (ICTs) in an educational context within or outside the disciplinary scope, mark, for the statements below, a cross (X), according to its degree of agreement or disagreement. We created a questionnaire that was distributed according to the following categorization: computational thinking (Chart 01), use of Information and Communication Technologies (ICTs) in Chemistry classes, preparation and use of technological resources (Table 3), Integration of Information and Communication Technologies (ICTs) in Chemistry for High School classes (Table 4), updating the Professor of Chemistry in Information and Communication Technologies (ICTs) (Table 5). 
Table 3 - Categorization and Objectives.

\begin{tabular}{|c|c|}
\hline Categorização & Ghanijiet \\
\hline Computational Thinking & $\begin{array}{l}\text { - Diagnose the degree of agreement and disagreement regarding the } \\
\text { integration of ICTs in chemistry teaching - Identify the conceptions } \\
\text { revealed by chemistry teachers regarding the use of ICTs in chemistry } \\
\text { classes }\end{array}$ \\
\hline $\begin{array}{l}\text { Use of Information and } \\
\text { Communication } \\
\text { in Chemistry classes }\end{array}$ & $\begin{array}{l}\text { - Qualify and quantify the use of ICTs in the educational context } \\
\text { - Diagnose the use of Information and Communication Technologies } \\
\text { (ICTs) in chemistry classes in high school in } \\
\text { the state schools of the city of Manaus }\end{array}$ \\
\hline $\begin{array}{lll}\text { Preparation and } & \text { Use of } \\
\text { Technological Resources } & & \end{array}$ & $\begin{array}{l}\text { - Quantify the use of technological equipment in the educational } \\
\text { context. } \\
\text { - Detect what types of technological equipment have been used to teach } \\
\text { chemistry }\end{array}$ \\
\hline $\begin{array}{l}\text { Integration of Information and } \\
\text { Communication Technologies (ICTs) } \\
\text { in Chemistry classes for } \\
\text { High School }\end{array}$ & $\begin{array}{l}\text { - Diagnose the degree of difficulty of teachers in relation to the integration } \\
\text { of ICTs in chemistry teaching }\end{array}$ \\
\hline $\begin{array}{l}\text { Update of the Professor of Chemistry } \\
\text { in Information and Communication } \\
\text { Technologies (ICTs). }\end{array}$ & $\begin{array}{l}\text { - Diagnose the need for an update of the professional who teaches the } \\
\text { discipline of chemistry, so that he can integrate the ICTs to the teaching } \\
\text { and learning process in Chemistry. }\end{array}$ \\
\hline
\end{tabular}

Source: Own authorship.

\subsection{Research Subjects}

The data collection of the methodological part was planned for the application of questionnaires 1 and 2 and interview with 38 (thirty-eight) teachers of the District Coordination III of the city of Manaus, who teach in high school the discipline Chemistry.

As the number of teachers (population) was small, it was decided to work with the total number, with no statistical error in this case, since the sample size is equal to that of the population.

\subsection{Data Processing Strategy}

It was decided to use the Likert Scale with degrees of agreement (variation from one to five), and some open questions. The questions of the Likert Scale would guarantee data from the experiences of the teachers involved in the process and allow to statistically modulate the results obtained in the research, which would provide a substantial view of theory-practice confrontation.

For a better analysis of the results of the research using the Likert Scale, we chose to make a quantitative analysis to establish the Mean Ranking (MR) for the questionnaire, to measure the degree of agreement of the subjects who answered the questionnaires.

It is possible to verify the agreement or disagreement of the evaluated questions, by obtaining the MR of the score attributed to the answers, relating to the frequency of the answers of the respondents.

Weighted Average $(\mathrm{MP})=\Sigma($ fi. Vi)

MRI is obtained by dividing the weighted average by the number of respondents.

Thus the RM = MP / (NS) Where: $\mathrm{fi}=$ observed frequency of each response for each item; $\mathrm{Vi}=$ value of each answer; NS $=$ No. of subjects.

From this result it should be considered that teachers:

Disagree $/ \mathrm{RM}<3$ / Indifferent $/ \mathrm{RM}=3 /$ Agree $\bullet \mathrm{RM}>3$ 
The MRI was obtained from the score attributed to the answers, relating to the frequency of the answers of the respondents who made such attribution. Values greater than 3 are considered as concordant and, less than 3, as discordant, considering a 5- point scale. The value exactly 3 is considered "indifferent" or "without opinion", being the "neutral point", equivalent to the cases in which the respondents left blank.

The frequency of the subjects is taken by analyzing the number of answers of the participants for each of the questions. In questions related to the degree of agreement, regarding the integration of ICTs into the chemistry teachinglearning process corresponding to Category "A" the options 1 to 5 mean:

1 Totally Disagree, 2 Disagree , 3 No Opinion , 4 Agree and 5 corresponds to the maximum degree of agreement, i.e., I totally agree.

For the calculation of MRI, the Likert scale analysis method is used (Malhotra, 2001; Tresca \& De Rose JR., 2004).

\section{Results and Discussion}

Of the 38 (thirty-eight) teachers who were supposed to participate in the research, only 30 (thirty) answered the questionnaires and the recorded interview, which corresponds to $78.9 \%$ of the population. In this case, the relationship between the sample studied and the population considered is still very high, and the statistical error in this case is close to zero.

There was also resistance from the school management and some teachers in relation to the researchers responsible for collecting and applying their research in the school environment, this is understandable, since often the final result points only to negative aspects of pedagogical development, disregarding the practical and/or theoretical contributions of these institutions.

Moreover, the difficulty encountered by schools in making schedules available so that teachers could answer the questionnaires was a negative fact in conducting the research, since it ended up depending on the permission of the institution's director or the available time of the chemistry curriculum discipline. In this sense, some teachers felt inhibited in participating in the interview stage. Thus, the acceptance of teachers in relation to interviews and the availability of schedules and physical space in school were included as criteria, thus allowing the implementation of this stage of the research.

The tabulation of personal data is presented in Table 4 and this sampling revealed a teacher profile with the following characteristics:

Table 4 - Profile of Chemistry Teachers Participating in the Research.

\begin{tabular}{|c|c|c|c|c|}
\hline Sex & Age Group & Graduation & Graduate & $\begin{array}{c}\text { Teaching time } \\
\text { (media) }\end{array}$ \\
\hline $\begin{array}{l}\text { Male } \\
25 \%\end{array}$ & $\begin{array}{l}+20 \text { Years } \\
30 \%\end{array}$ & Bachelor $20 \%$ & Masters $6,66 \%$ & 3 Years (20-29 Years) \\
\hline \multirow[t]{2}{*}{$\begin{array}{l}\text { Female } \\
75 \%\end{array}$} & $\begin{array}{l}+30 \text { Years } \\
60 \%\end{array}$ & Degree $60 \%$ & Experts $40 \%$ & $\begin{array}{c}12 \text { Years }(30-39 \\
\text { years })\end{array}$ \\
\hline & $\begin{array}{l}+40 \text { Years } \\
10 \%\end{array}$ & $\begin{array}{l}\text { Related } \\
20 \%\end{array}$ & & 15 Years $(+40$ Years $)$ \\
\hline
\end{tabular}

Source: Own authorship. 
Table 4 shows that the predominance is female, with the most representative age group over 30 years and approximately 12 years of teaching. The majority 70 have a degree in Chemistry, however, less than $50 \%$ of the teachers interviewed continued to study. As an example, it is possible to analyze the case of Question 1 in the Table 5:

Table 5 - Obtaining a Mean Ranking (RM) for Question 1.

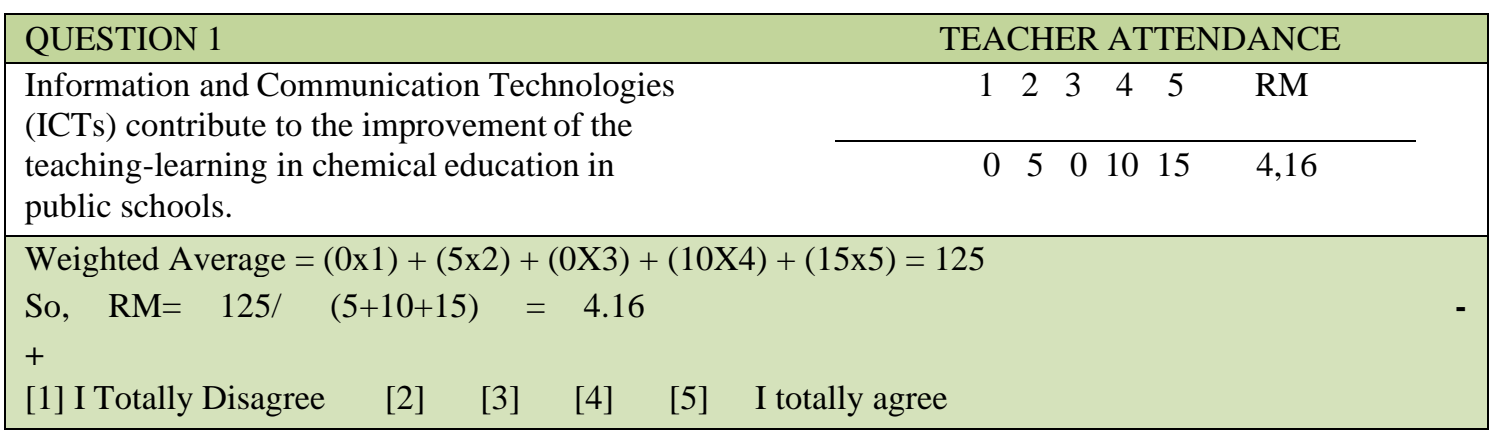

Source: Own authorship.

Table 6 represents the MR of the questions referring to the Category "Computational Thinking" in the Likert scale. This table assisted in the interpretation of the results, for all categories, we applied this frequency, from the Weighted Average obtained from the data collected in the research, for each of the questions, applied in Questionnaire 2.

Table 6 - Questions, Number of Answers and Average Ranking Value of the Category "Computational Thinking".

\begin{tabular}{|c|c|c|c|c|c|c|}
\hline Issues & DT & D & SO & $\mathrm{C}$ & CT & $\mathrm{RM}$ \\
\hline $\begin{array}{l}\text { 1. Do Information and Communication Technologies (ICTs) } \\
\text { contribute to the improvement of the teaching- } \\
\text { learning process in Chemical Education in public schools? }\end{array}$ & 0 & 5 & 0 & 10 & 15 & 4,16 \\
\hline $\begin{array}{l}\text { 2. Does integrating search sites improve the teaching- } \\
\text { learning process of Chemistry in high school? }\end{array}$ & 3 & 7 & 0 & 5 & 15 & 3,73 \\
\hline $\begin{array}{l}\text { 3. Does integrating specific sites improve the teaching- } \\
\text { learning process of Chemistry in high school? }\end{array}$ & 0 & 3 & 2 & 7 & 18 & 4,33 \\
\hline $\begin{array}{l}\text { 4. Does integrating educational software improve the teaching } \\
\text { and learning process of Chemistry in high } \\
\text { school? }\end{array}$ & 0 & 0 & 0 & 5 & 25 & 4,83 \\
\hline $\begin{array}{l}\text { 5. Does integrating educational videos improve the process of } \\
\text { teaching and learning Chemistry in high school? }\end{array}$ & 0 & 0 & 0 & 3 & 27 & 4,90 \\
\hline $\begin{array}{l}\text { 6. Does integrating virtual experimental classes improve the } \\
\text { process of teaching and learning Chemistry in high } \\
\text { school? }\end{array}$ & 0 & 0 & 0 & 1 & 29 & 4,96 \\
\hline $\begin{array}{l}\text { 7. Integrate in your chemistry classes, materials taken from the } \\
\text { Internet }\end{array}$ & 0 & 0 & 0 & 15 & 15 & 4,50 \\
\hline $\begin{array}{l}\text { 8. Would integrating ICTs in the teaching of Chemistry } \\
\text { awaken in the student the desire to learn this Science? }\end{array}$ & 0 & 5 & 0 & 7 & 18 & 4,26 \\
\hline $\begin{array}{l}\text { 9. Would integrating ICTs into chemistry teaching, the } \\
\text { teaching and learning process in high school, improve the } \\
\text { student's perception of its importance to society? }\end{array}$ & 0 & 2 & 0 & 5 & 25 & 4,63 \\
\hline
\end{tabular}

Legend: DT= Totally Disagree; $\mathrm{D}=\mathrm{I}$ disagree; $\mathrm{SO}=$ No opinion; $\mathrm{C}=\mathrm{I}$ agree; $\mathrm{CT}=\mathrm{I}$ totally agree. Source: Own authorship. 
The first issue of Chart 6, aims to investigate the perceptions of teachers regarding ICTs contribute to the Teaching of Chemistry in public schools in Manaus. The RM value equal to 4.16 expresses the great degree of agreement with this statement. This optimism reflects the great investment that the Government of the State of Amazonas made, distributing to all its teachers a computer.

Despite the motivation expressed in the result of this first question, others need to be raised from this initial statement, so that this enthusiasm is not transformed into a naïve view of the use of ICTs in school, in order to ascertain how the contributions from ICTs are effectively processed, and thus obtain a critical view to identify possible obstacles arising from these interactions, which undermine the integration of ICTs in chemistry teaching in high school.

Graph 1 - Contribution of ICTs to the Teaching-learning Process in Chemistry.

\section{Do Information and Communication Technologies \\ (ICTs) contribute to the improvement of the teaching and learning process and chemistry teaching in public schools?}

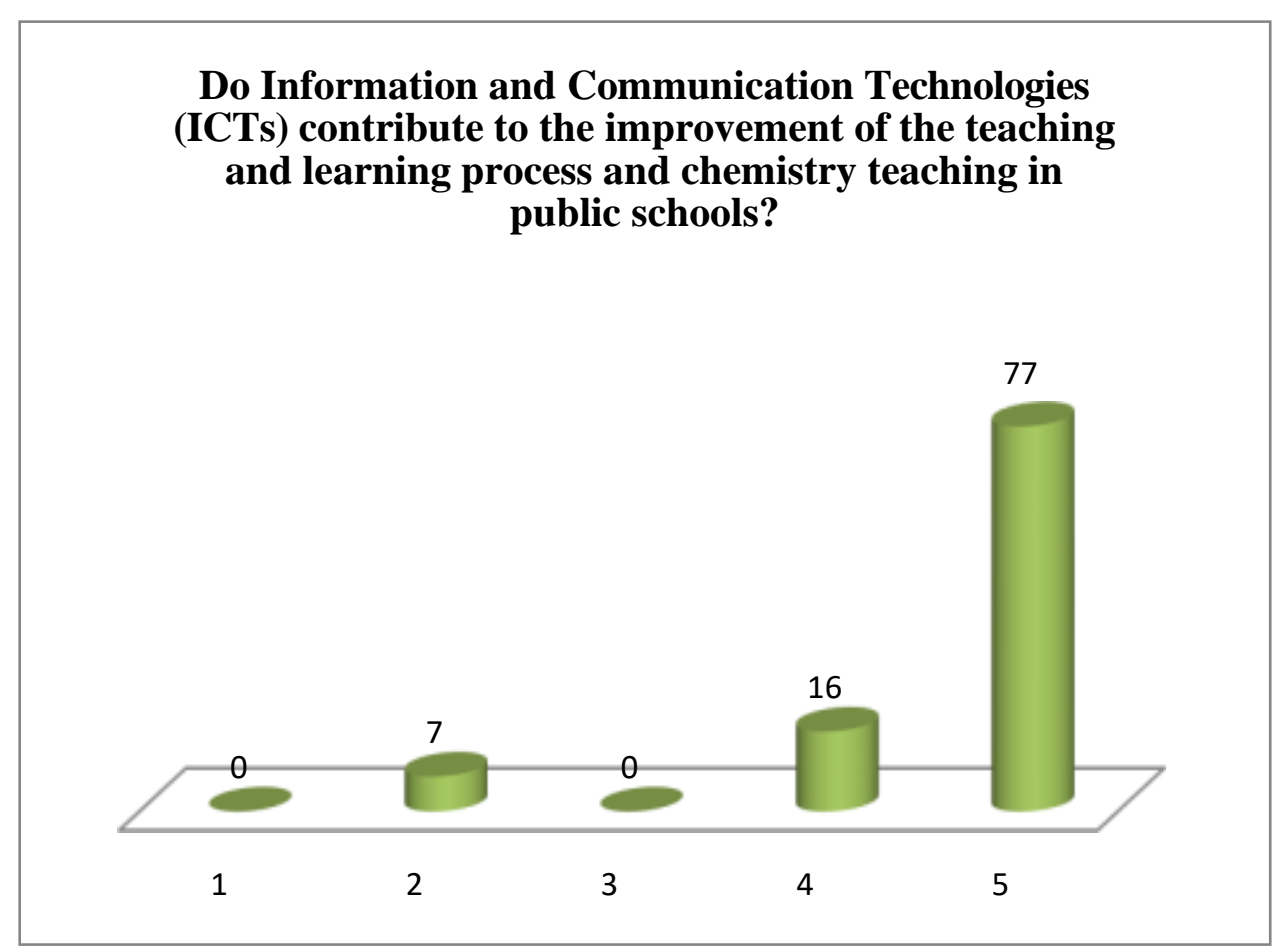

Legend: $1=$ Totally Disagree; 2= I disagree; 3= No Opinion; 4= I agree; 5=Totally agree. Source: Own authorship

As shown in Graph 1, exactly $50 \%$ of teachers totally agree that ICTs contribute to the teaching-learning process in Chemistry Teaching, however, if we add the categories "I totally agree" and "Totally agree", attributed to the degree of agreement, $83 \%$ of teachers agree with this statement. 
Graph 2 - Integration of ICTs in the Chemistry Teaching-Learning Process as a motivating factor for the student.

\section{Would integrating ICTs in chemistry teaching awaken in the student the desire to learn this Science?}

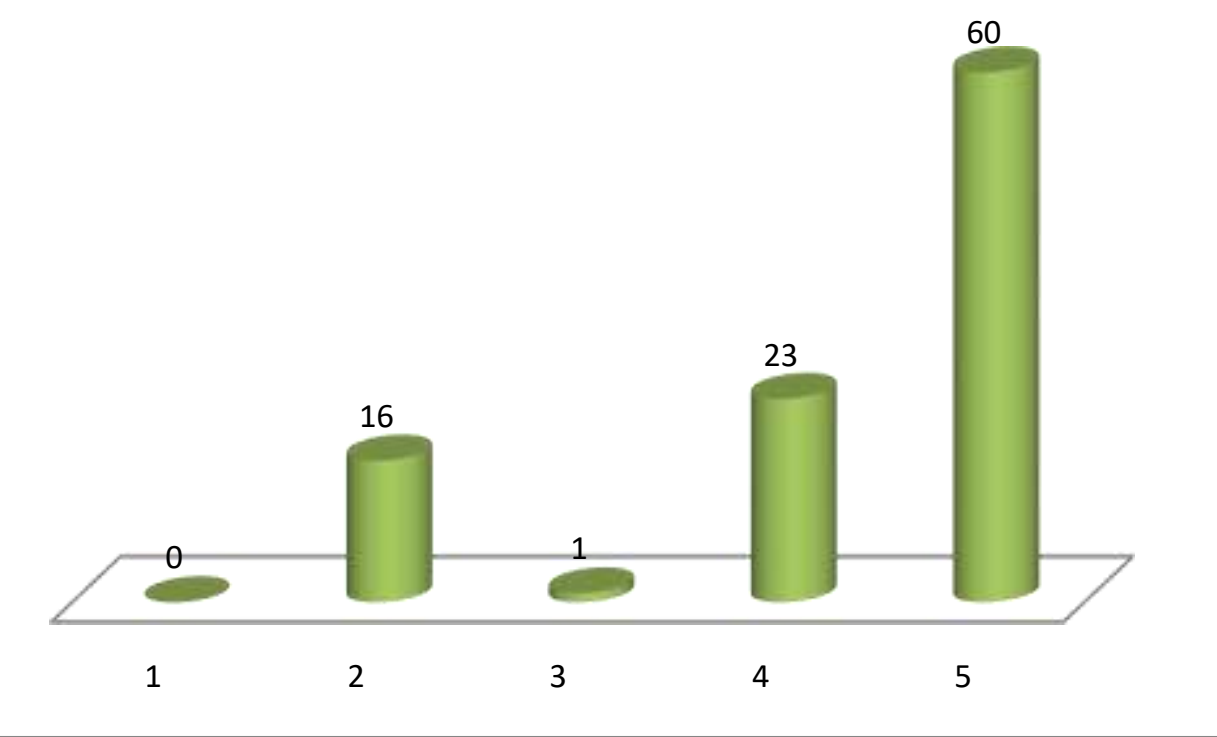

Legend: 1= Totally Disagree; 2= I disagree; 3= No Opinion; 4= I agree; 5=Totally agree. Source: Own authorship.

Relating the results of Question 8 presented in Graph 2, with Question 9 presented in Graph 3, questions from the Category "Computational Thinking", we observed that $60 \%$ of teachers affirm that integrating ICTs in chemistry teaching would awaken the student's desire to learn this science. They agree with this statement $83 \%, 16 \%$ disagree, while $77 \%$ say that this integration would improve the student's perception, regarding the importance of this discipline for society and $93 \%$ of the interviewees agree that this statement is true, that is, only $7 \%$ disagree with this situation under analysis. These data lead to the statement that teachers are interested in awakening in the student the desire to learn chemistry, motivate him. The question of achieving this goal is the strategy used. It is worth mentioning again Kalhil (2003) with regard to the strategy: develop previously planned tasks or actions that lead to the achievement of the pre-established objectives based on a methodology elaborated for this purpose, during the pedagogical process. In the strategic planning of these tasks or actions, ICTs are very important tools. 
Graph 3 - Integration of ICTs in the Process of Teaching-Learning Chemistry and its Importance to Society.

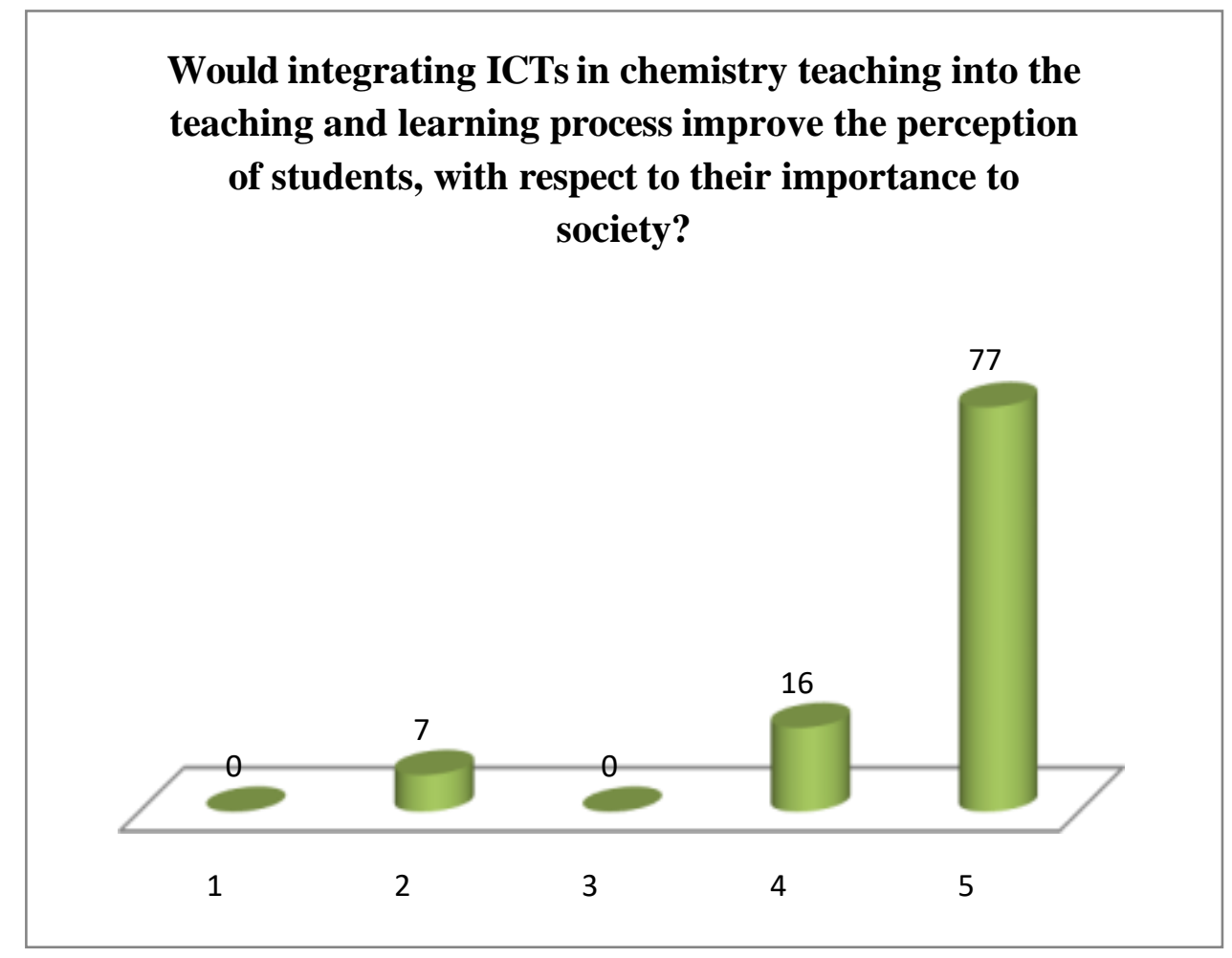

Legend: 1= Totally Disagree; 2= I disagree; 3= No Opinion; 4= I agree; 5=Totally agree. Source: Own authorship.

Graphs 2 and 3 show the degree of agreement in the use of ICTs as a motivating factor for students in learning chemistry contents, in addition to understanding the importance of this discipline for their life in society.

Table 7 - Questions, Number of Answers and Average Ranking Value of the Category "Use of (ICTs) in Chemistry classes".

\begin{tabular}{|l|c|c|c|c|c|c|}
\hline \multicolumn{1}{|c|}{ Issues } & I & PU & SU & U & MU & RM \\
\hline $\begin{array}{l}\text { 10. In the ministry of your Chemistry classes in your school, } \\
\text { does the integration of ICTs happen so that the teaching- } \\
\text { learning process in Chemistry is ethical, }\end{array}$ & 7 & 15 & 6 & 2 & 0 & 2,1 \\
\hline dynamic and contextualized? & & & & & & \\
\hline $\begin{array}{l}\text { 11. In the use of ICTs, is it integrated in your classes, specific } \\
\text { sites of Chemistry? }\end{array}$ & 27 & 2 & 0 & 1 & 0 & 1,16 \\
\hline $\begin{array}{l}\text { 12. In the use of ICTs, is it integrated into your } \\
\text { chemistry classes, search engines? }\end{array}$ & 28 & 1 & 0 & 1 & 0 & 1,13 \\
\hline $\begin{array}{l}\text { 13. In the use of ICTs, is it integrated into your classes of, } \\
\text { chemistry, educational software? }\end{array}$ & 11 & 18 & 0 & 1 & 0 & 1,7 \\
\hline $\begin{array}{l}\text { 14. In the use of ICTs, is it integrated into your classes } \\
\text { of chemistry, educational videos? }\end{array}$ & 18 & 10 & 0 & 1 & 0 & 1,4 \\
\hline $\begin{array}{l}\text { 15. In the use of ICTs, is it integrated into your classes of, } \\
\text { chemistry, virtual experiments? }\end{array}$ & 28 & 2 & 0 & 0 & 0 & 1,06 \\
\hline $\begin{array}{l}\text { 16. In the use of ICTs, is it integrated into your } \\
\text { chemistry classes, materials taken from the Internet? }\end{array}$ & 18 & 5 & 2 & 5 & 0 & 1,8 \\
\hline
\end{tabular}

Legend: I= Useless; PU= Not Very Useful; SU= No Utility; U= Useful; MU= Very Useful Source: Own authorship. 
Teachers have acquired information about the integration of ICTs to teach chemistry, through professional experience, autonomy, from their own colleagues and through students, which is no surprise, because the Report of the Internet Steering Committee in Brazil prepared in 2010 concluded: "Young people know how to use computers and the Internet, as well as all other modern technologies, much more effectively, probably because they acquire skills in a more natural way, by curiosity and creativity proper to age".

The understanding that science is not done in isolation is fundamental for the intellectual growth of the teacher and the student, this interactivity and distinct perspectives in this construction, can significantly interfere in the process of teaching and learning chemistry. ICTs should assist in the task of proposing didactic sequences that serve simultaneously for the teacher and student learning process (Trivelato, 2003) It is important to relate these responses with what Castells (2000) says in relation to the Information Society. Education was one of the most affected areas of human activity and the teacher in an empirical way was pushed to seek knowledge in ICTs.

Table 7 shows that $63.33 \%$ of teachers highlight that their knowledge exists through the use of programs or software.

Graph 4 - Tools That Can Be Integrated into the Chemistry Teaching and Learning Process.

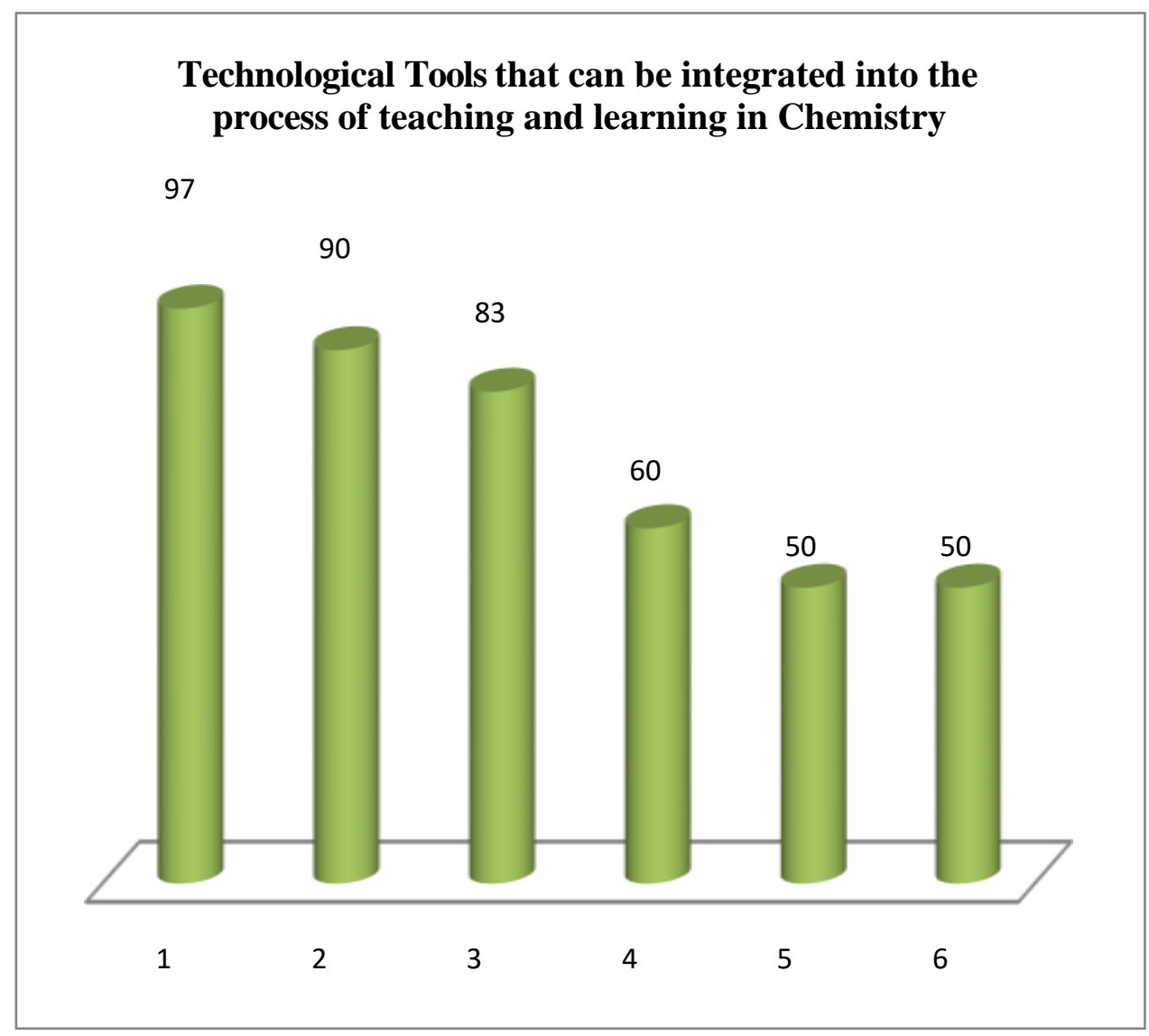

Legend: $1=$ Experimental Classes; $2=$ Explanatory Videos; $3=$ Educational Software; $4=$ Specific Sites; $5=$ Search Sites; $6=$ Internet Materials Source: Own authorship.

Graph 4 shows that in the view of $97 \%$ of teachers could be integrated into experimental chemistry classes, then educational videos with $90 \%$ and thirdly software with $83 \%$. This fact is justified by the difficulty of conducting experimental classes in public schools, due to the high cost of materials and chemicals needed for a practical class. Some 
teachers, during the interview, also reported the desire to find more software in specialized stores, but according to them, it is difficult and when they find it is high cost. The issue of tools involving the Internet is related in the last placement, with only $50 \%$ and it is likely that this low rate is related to the fact that not all schools have Internet access.

Table 8 - Questions, Number of Answers and Average Ranking Value of the Category "preparation and use of technological resources"

\begin{tabular}{|l|c|c|c|c|c|c|}
\hline \multicolumn{1}{|c|}{ Issues } & NU & UP & UR & UM & UT & RM \\
\hline $\begin{array}{l}\text { 17. Specifically in the preparation and execution of } \\
\text { your chemistry classes, does the use of the computer } \\
\text { happen? }\end{array}$ & 0 & 2 & 4 & 22 & 2 & 3,8 \\
\hline $\begin{array}{l}\text { 18. Specifically in the preparation and execution of your } \\
\text { chemistry classes, does the use of television } \\
\text { happen? }\end{array}$ & 0 & 16 & 6 & 8 & 0 & 2,73 \\
\hline $\begin{array}{l}\text { 19. Specifically in the preparation and execution of } \\
\text { your chemistry classes, does the use of radio happen? }\end{array}$ & 30 & 0 & 0 & 0 & 0 & 1 \\
\hline
\end{tabular}

Legend: $\mathrm{NU}=$ does not use; $\mathrm{UP}=$ use little; $\mathrm{UR}=$ use regularly; $\mathrm{UM}=\mathrm{I}$ use a lot; $\mathrm{UT}=\mathrm{I}$ use it completely. Source: Own authorship.

It is possible to verify through Table 8 that of the technological equipment analyzed, radio is not used by any teacher, while television is used by $53 \%$ and the computer by $80 \%$ of the interviewees, which is justified by the enormous amount of information and resources that the Internet makes available through the computer.

Graph 5 - Use of Technological Equipment.

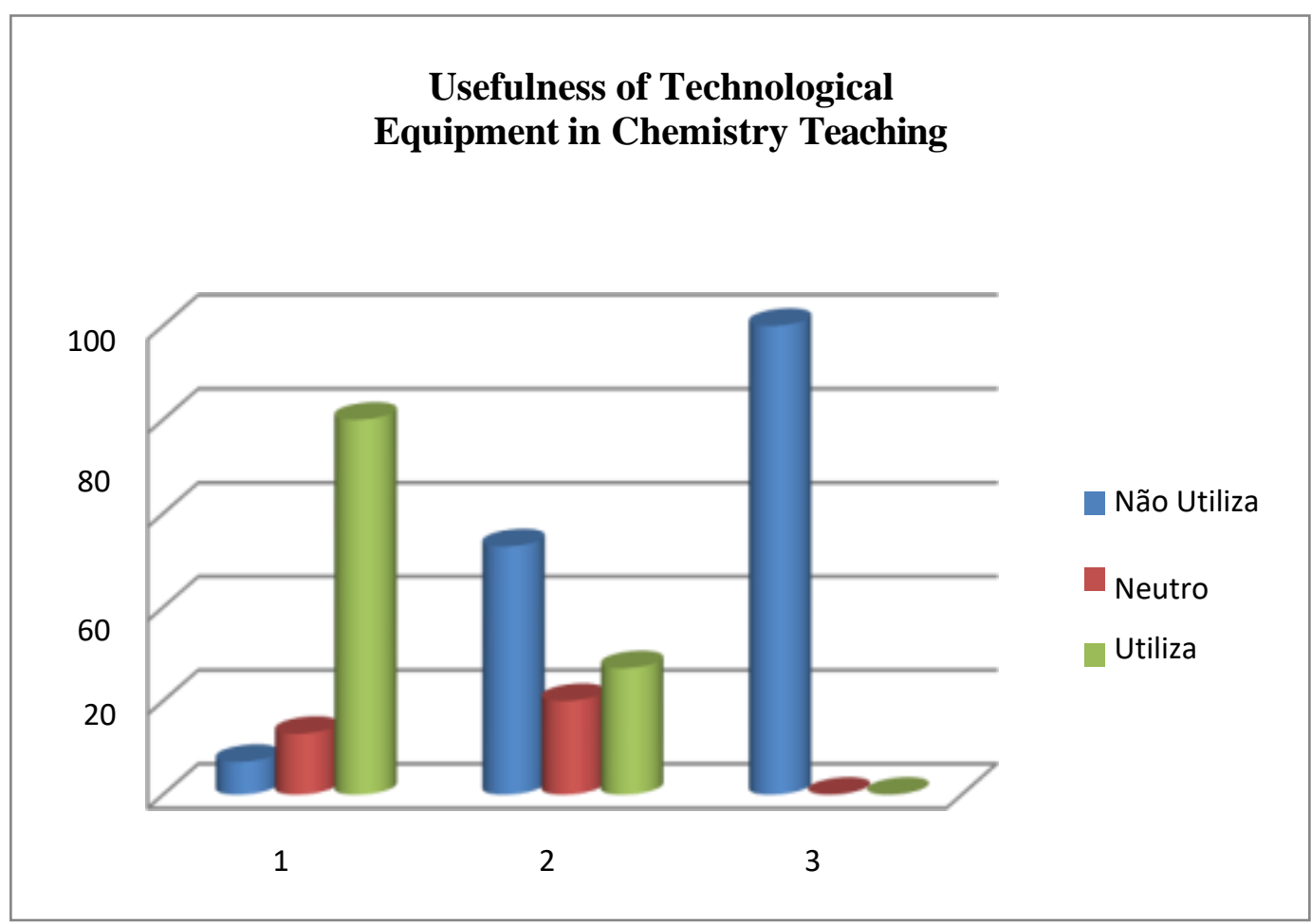

Legend: 1- Computer; 2- Television; 3- Radio Source: Own authorship. 
As the computer is the technological equipment most used by teachers and because of the relevance of information, these data are presented in Graph 5. However, in the analysis of Graph 6, in agreement with RM 3.8 related to the category "adding the categories "Uses A Lot" and "Totally Uses", the degree of agreement is $80 \%$, that is, teachers state that the computer is the most used equipment in the schools analyzed to teach chemistry. In the questions related to the degree of agreement, regarding the integration of ICTs to the process of teaching- learning chemistry, corresponding to Category "D" the options 1 to 5 mean: 1 "Very Difficult", 2 "Difficult", 3 "Normal", 4 "Easy" and 5 corresponds to the maximum degree of agreement, i.e. "Very Easy".

Graph 6 - Teachers' Opinion on the Need for a Specialization Course to Integrate ICTs in Chemistry Teaching.

\section{Teachers' opinions regarding the need for specialization course involving ICTs in Chemistry Teaching}

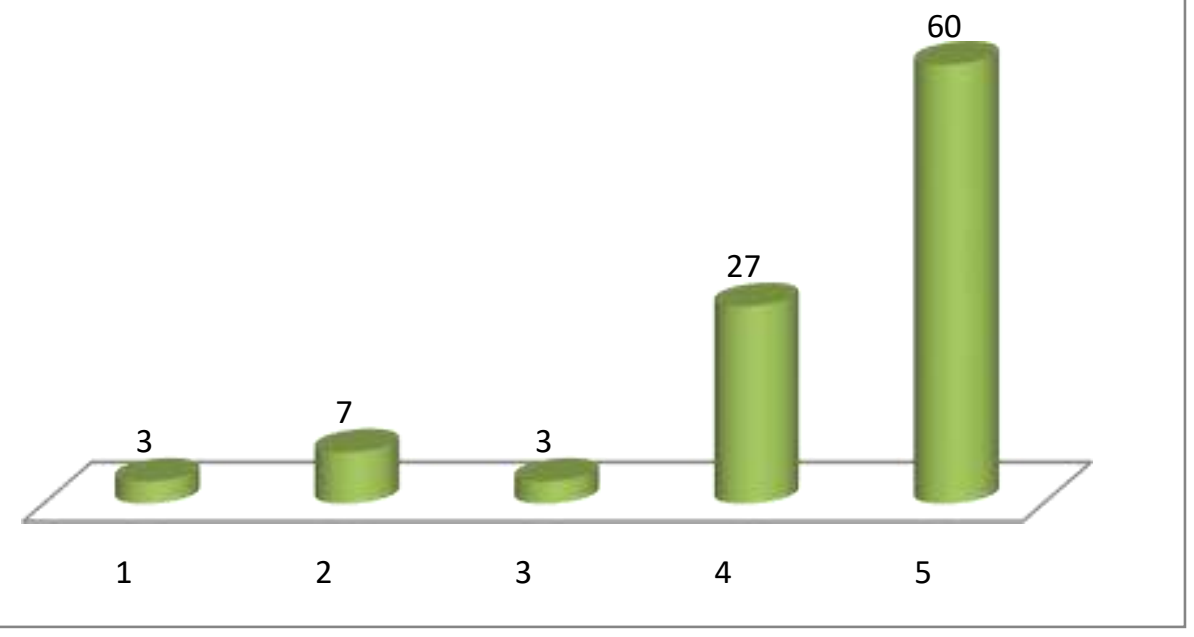

Legend: $1=$ No need; $2=$ Not Very Necessary; $3=$ Reasonable; $4=$ Very Necessary; $5=$ Super Needed. Source: Own authorship.

In the analysis of Graph 6, adding the categories "Uses A Lot" and "Totally Uses", the degree of agreement is 80\%, that is, teachers state that the computer is the most used equipment in the schools analyzed to teach chemistry.

Table 9 - Questions, Number of Answers and Value of Medium Ranking of the Category "Integration of Information and Communication Technologies (ICTs) in Chemistry classes for High School".

\begin{tabular}{|c|c|c|c|c|c|c|}
\hline Issues & MD & D & $\mathrm{N}$ & $\mathrm{F}$ & MF & $\mathrm{RM}$ \\
\hline $\begin{array}{l}\text { 20. Regarding the integration of ICTs in Chemistry } \\
\text { Teaching, the teaching-learning process in high school, you } \\
\text { would say that it is }\end{array}$ & 0 & 8 & 15 & 5 & 2 & 3,03 \\
\hline $\begin{array}{l}\text { 21. Regarding the integration of ICTs in chemistry teaching, } \\
\text { the teaching-learning process in the } 1 \text { st year } \\
\text { of high school, you would say that it is... }\end{array}$ & 7 & 4 & 13 & 5 & 1 & 2,63 \\
\hline $\begin{array}{l}\text { 22. Regarding the integration of ICTs in chemistry teaching, } \\
\text { the teaching-learning process in the } 2 \text { nd } \\
\text { year of high school, you would say that it is... }\end{array}$ & 4 & 5 & 16 & 4 & 1 & 2,4 \\
\hline $\begin{array}{l}\text { 23. Regarding the integration of ICTs in chemistry teaching, } \\
\text { the teaching-learning process in the } 3 \text { rd year } \\
\text { of high school, you would say that it is... }\end{array}$ & 2 & 8 & 15 & 5 & 0 & 2,76 \\
\hline
\end{tabular}


Agree $\bullet$ RM > 3 Indifferent / RM = 3 Disagree RM < 3 Source: Own authorship.

The results obtained, condensed in Table 9 , are presented through Graph 9 for a better visualization. The category "Very difficult" and "Hard" were added to obtain the assignment of "difficulty" and added the categories "Very easy" and "Easy" to obtain the assignment of "ease".

Graph 7 - Degree of Difficulty in Integrating ICTs in Chemistry Teaching.

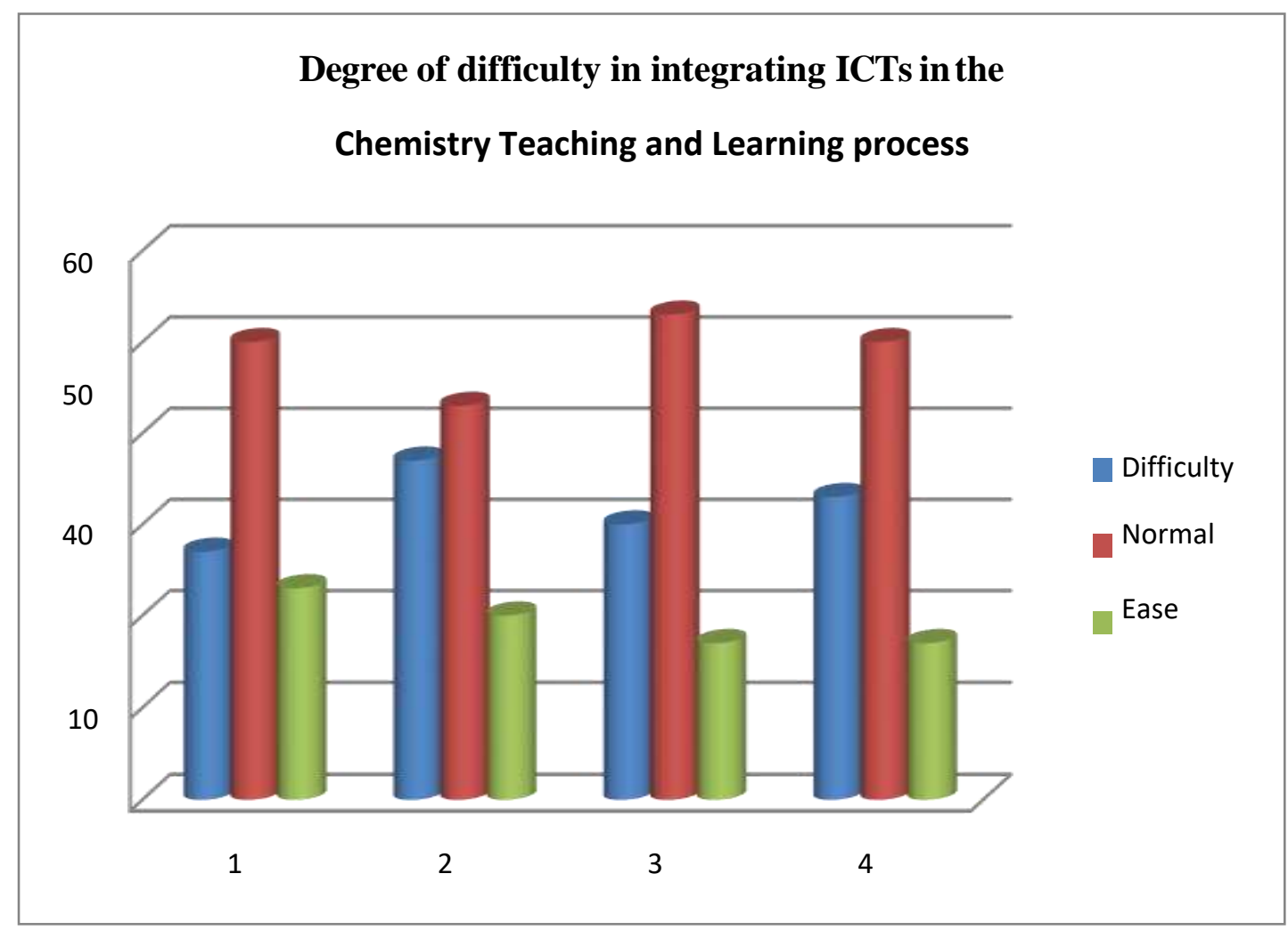

Legend: 1= High School; 2= 1st Year; 3=2nd Year; 4=3rd Year. Source: Own authorship.

By means of Table 10 it is clear that educators are aware that the integration of Ikte in Chemistry in that Hoërskool is desirable. That chart also shows that the degree of difficulty in that selection and preparation of Chemistry class using Ikte is an important fact in today's world.

Table 10 - Questions, Number of Answers and Average Ranking Value of the Category "Update of the Professor of Chemistry in Information and Communication Technologies (ICTs)".

\begin{tabular}{|c|c|c|c|c|c|c|}
\hline Issues & $\mathrm{N}$ & $\mathrm{MN}$ & RN & PN & SN & RM \\
\hline $\begin{array}{l}\text { 24. In his view, integrating ICTs into chemistry teaching } \\
\text { would be... }\end{array}$ & 0 & 2 & 3 & 6 & 19 & 4,4 \\
\hline $\begin{array}{l}\text { 25. In his point of view, the chemistry teacher needs to } \\
\text { know and apply the ICTs so that the teaching } \\
\text { learning process achieves the desired objectives... }\end{array}$ & 4 & 5 & 5 & 4 & 12 & 3,5 \\
\hline $\begin{array}{l}\text { 26. In his view, a continuing education involving ICTs to } \\
\text { chemistry teaching would be... }\end{array}$ & 0 & 0 & 0 & 1 & 12 & 2,13 \\
\hline $\begin{array}{l}27 \text { In his view, a specialization course involving ICTs to } \\
\text { chemistry teaching would be... }\end{array}$ & 1 & 2 & 1 & 8 & 18 & 4,33 \\
\hline
\end{tabular}


Legend: $\mathrm{N}=$ required; $\mathrm{MN}=$ very necessary; $\mathrm{RN}=$ reasonably necessary; $\mathrm{PN}=$ little needed; $\mathrm{SN}=$ no need. Source: Own authorship. Of the teachers interviewed, 57\% did not answer the "Question 26" belonging to questionnaire 2 and the "Question 14" of questionnaire 1 for not having knowledge about what a continuing education is, hence an MRI of 2.13. Here it is important to emphasize that of the 13 teachers who responded, and that, therefore, it is assumed that they know what a continuing education is, 12 claim to be "Super necessary" and 1 states that it is "Very necessary".

Graph 8 - Teachers' Opinion on the Need to Know and Apply ICTs so that the Objectives of the Teaching-Learning Process in Chemistry are Achieved.

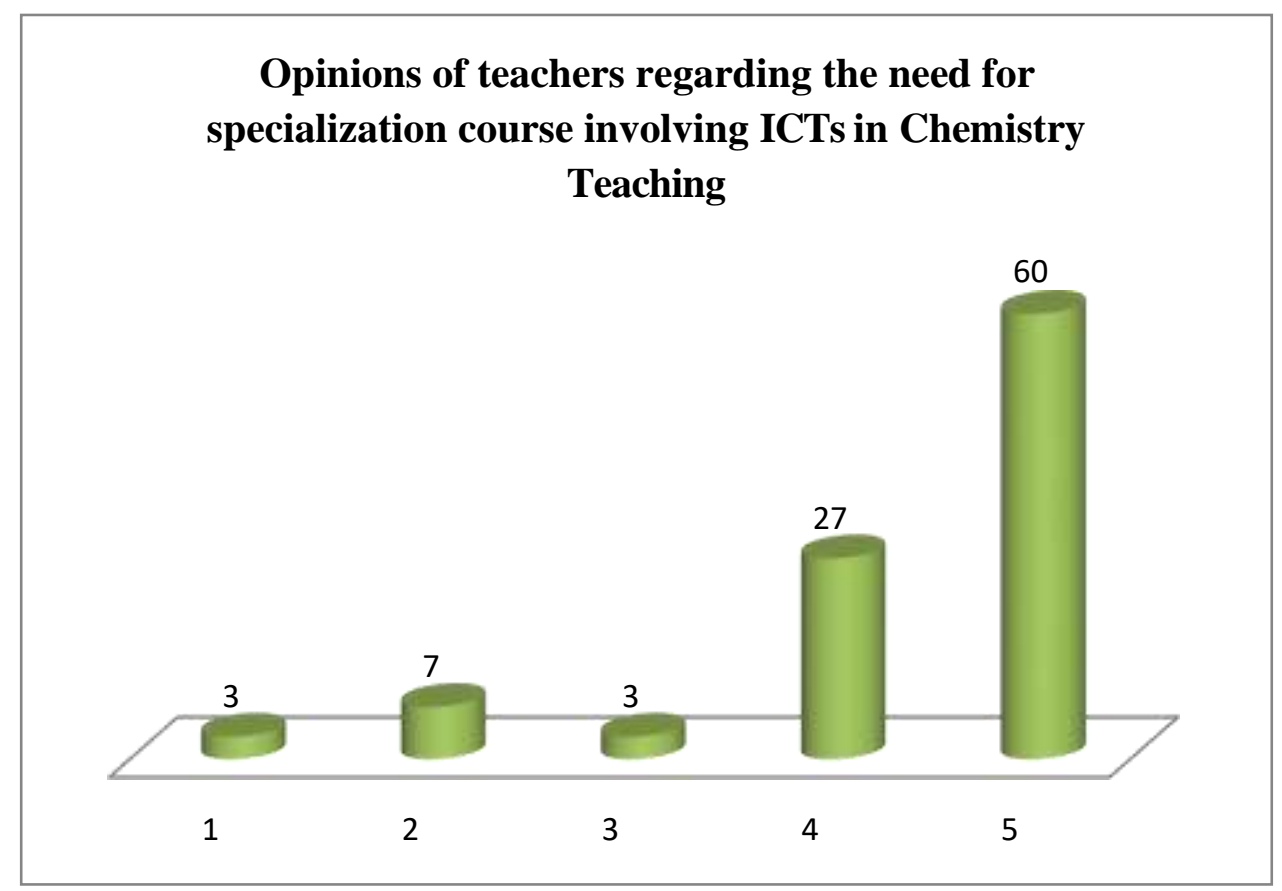

Legend: $1=$ No Need; $2=$ Not Very Necessary; $3=$ Reasonable; 4= Very Necessary; 5= Super Needed. Source: Own authorship.

As can be seen in Table 10, chemistry teachers express an MRI 3.5 for question 25, corresponding to a degree of agreement by adding the categories "Very necessary" with the category "Super needed" around 53\% and a degree of disagreement, adding the category "No need" with "Little needed" in $30 \%$.

Graph 8 expresses the conceptions of the interviewed teachers regarding the need for a specialization course integrating ICTs to chemistry teaching. When adding the amount of answers, "very necessary" and "super necessary" a value of $87 \%$ of the teachers interviewed identify this need, while only $10 \%$ disagree, which points significantly to the need for continuing education courses. 
Graph 9 - Teachers' Opinion on the Need to Know and Apply ICTs so that the Objectives of the Teaching-Learning Process in Chemistry are Achieved.

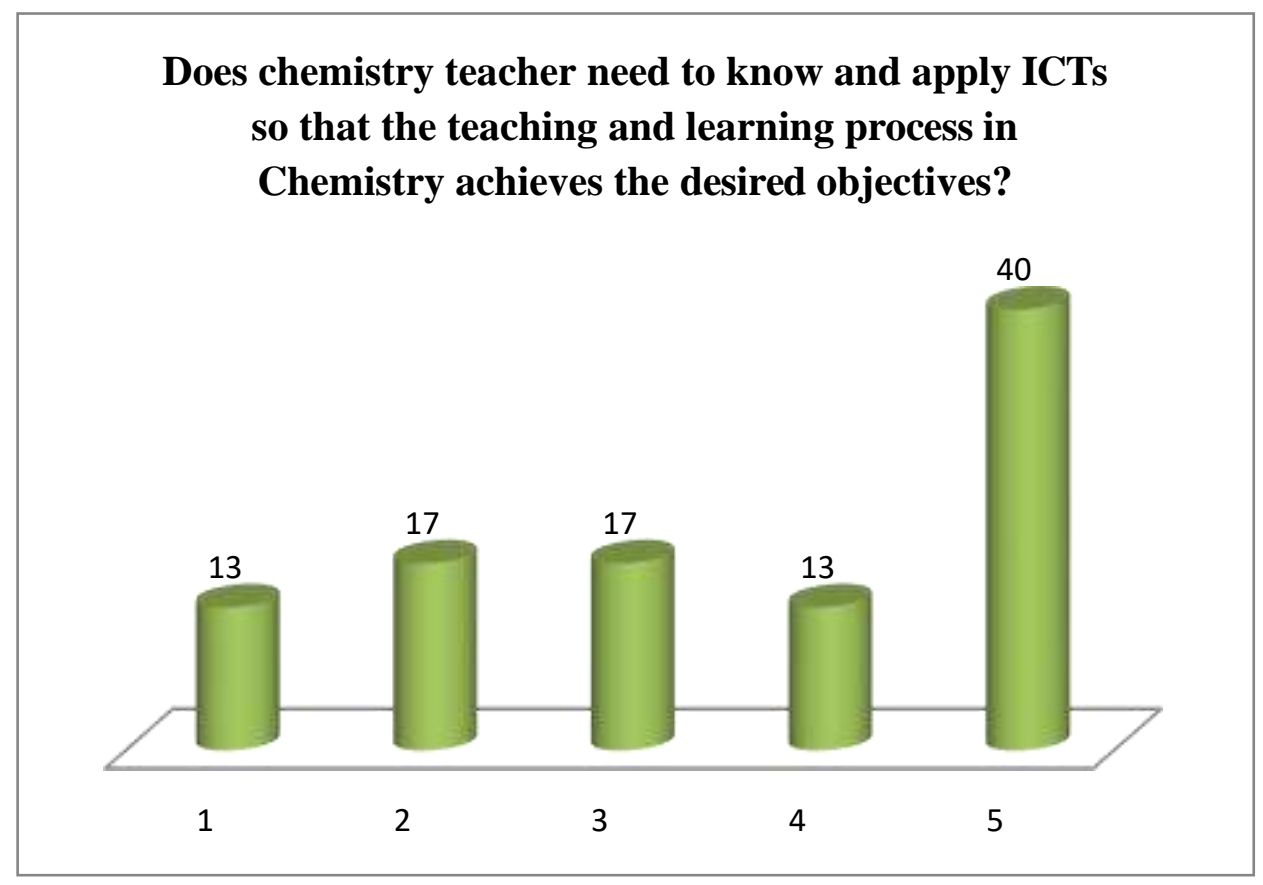

Legend: 1= No Need; 2= Not Very Necessary; 3= Reasonable; 4= Very Necessary; 5= Super Needed Source: Own authorship.

As can be seen in Chart 9, chemistry teachers express an MRI 3.5 for question 25, corresponding to a degree of agreement by adding the categories "Very necessary" with the category "Super needed" around 53\% and a degree of disagreement, adding the category "No need" with "Little needed" in 30\%.

Graph 10 - Opinion on the Need for ICT Integration in the Teaching and Learning Process in Chemistry in High School.

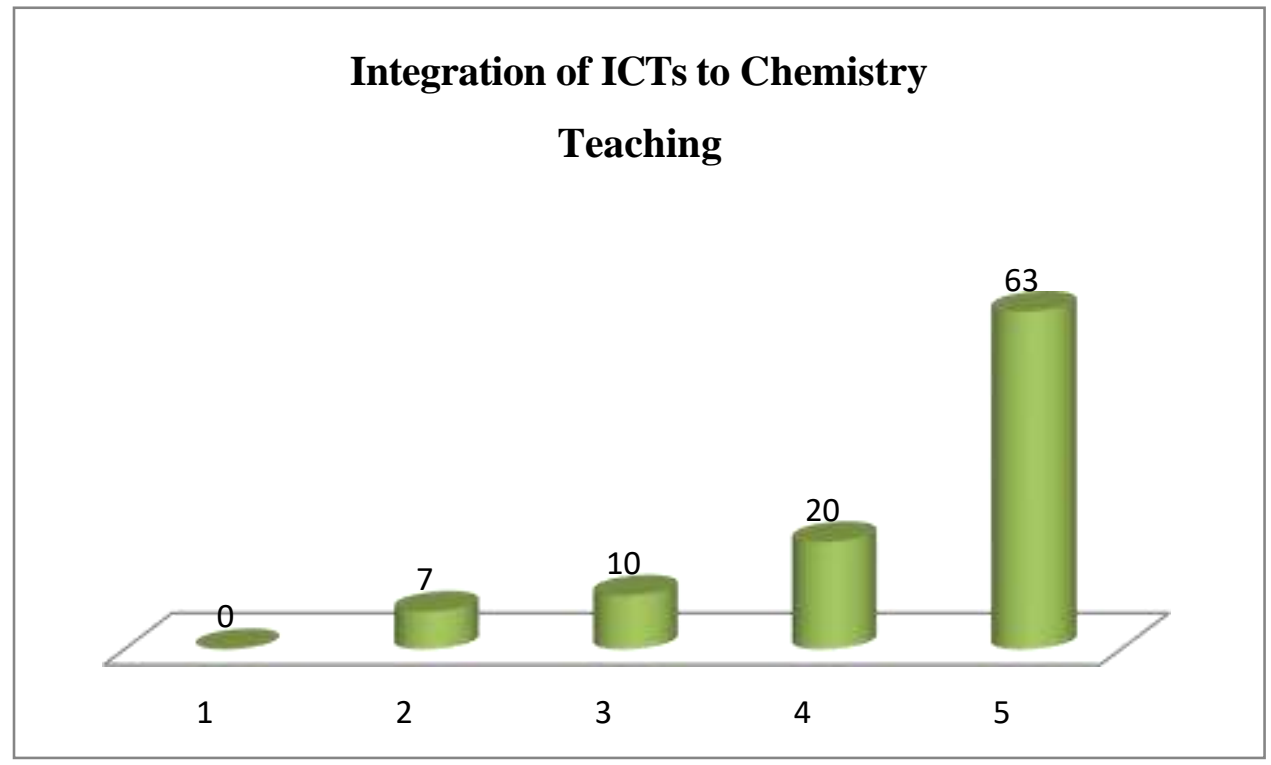

Legend: $1=$ No Need; $2=$ Not Very Necessary; 3= Reasonable; 4= Very Necessary; 5= Super Needed. Source: Own authorship

RM 4.4 is presented in Chart 9, where the maximum degree of agreement with relation to need corresponds to $63 \%$ in the opinions of the interviewed teachers. When adding the categories "Very necessary" with "Super needed" we have a 
degree of agreement of $83 \%$. The result is an indication for the proposal of this dissertation to be considered, analyzed and applied. With this we will be contributing to the improvement of the teaching-learning process in chemistry in public schools in Manaus.

\section{Conclusion}

The Government of Amazonas realizing this distant relationship has provided computer networks, internet and multimedia projectors in an attempt to bring the current cyber student closer to the classroom and the teacher. However, this approach has not had the expected success and this research sought not only to try to understand this problem, but also to present solutions that, together with other proposals, minimize this regional problem.

It is understood that the value of any technology for the Teaching of Chemistry is not in itself, but depends on the use that can be made of it. What can be produced as scientific knowledge can be mediated by the technological tools and resources that are used, but the content, or rather the essence, the fragrance of this production depends on the path that is taken on the road of life, our look at the importance of Chemistry in the lives of our students, our skills and competencies, our social responsibility as a professional, everything is immersed in the sense of complexity that teachers can chemically express, living and characterizing our attitudes and words and demonstrating the meaning of chemistry contents for the social life of our students.

From the state of the art, reading of scientific articles, participation in scientific events and the results obtained in this research, it was possible to understand the importance and need of this research for the reality that is experienced in the Amazon context, specifically in Manaus, considering that, there are few publications, involving the integration of ICTs in chemistry teaching, there is a large gap to be filled through publications related to work that we teachers can produce , starting in the classroom.

When we seek to establish an investigation on Information and Communication Technologies (ICTs) and Chemistry Teaching at the present time, it was found that teachers who teach the discipline "Chemistry" in public schools, present a limited view with respect to that already modified.

Involved in the educational context, we must not forget that the coherence in the integration of ICTs to the Teaching of Chemistry and elementary, considering that we can not allow the student, only, "use by using" these technological tools, such as making posters to "decorate" the school spaces, use games only for "games" in the classroom, access only the internet without having a specific goal, type through the search sites what you need, making copies of requested works in a more sophisticated way. These technological tools should be used for the student to research, interact, acquire information, in order to collaborate in the construction of a dynamic and contextualized process, and not only to make copies of information, without any meaning in their knowledge.

Establishing an investigation on Information and Communication Technologies (ICTs) and Chemistry Teaching, it was found that teachers who teach the discipline "Chemistry" in public schools, present a limited view in relation to this theme.

It is understood that chemistry contents do not need to be explained, but new ways of teaching and learning need to be debated, constructed, socialized. Teamwork, the construction of scientific knowledge, the construction of experimental videos, the creation of projects with regional themes, the use of ICTs with these objectives, will leverage subsidies that will lead students to understand why they study this science in school and its essence in building a better society.

The questions that guided this research have the following answers: teachers from the state public school system did not receive specific instructions on the use of ICTs in undergraduate chemistry teaching or continuing education courses; the 
most used technological tools are those that do not need the Internet in school, describe the advantages and disadvantages of this process and a difficulty for most of them, due to the lack of information and knowledge; the statistical analysis performed through questionnaires that used the Likert scale, through a quantitative approach, allowed the association of data and the understanding of the existence of this need.

A positive fact is that there is the understanding on the part of teachers of the need to integrate ICTs in their classes, since $83 \%$ agree that integrating ICTs into the teaching-learning process in chemistry would contribute to its improvement, $83 \%$ agree that this integration is necessary, $93 \%$ say that it would improve the student's perception regarding the importance of discipline for society. But what can be seen with a nonsense is that only $17 \%$ of respondents use some ICT tools to teach Chemistry?

Only through study and knowledge can existing paradigms be broken and for this to happen, it is proposed a specialization course as an instrument that induces the teacher first to a reflection of their practices and thus effectively the existence of new conceptions about how, why, in what way, where, from what, involved in their reality could "Integrate the Teaching of Chemistry the ICTs"

The other issue theoretically addressed and also reflecting the need for refresher courses for teachers is the contextualization of what is taken for discussion with students. This contextualization that can be facilitated by the new Information and Communication Technologies is not automatic and requires teacher preparation. In chemistry courses, whether of medium or higher level, the potential of the Amazon should be valued, bringing in this context, the experiences of the local population.

The proposal of a specialization course presented in this research reflects the current state of the art and, as ICTs undergo rapid changes, new updating courses should follow trends, without leaving aside the issue of contextualization, fundamental to bring students closer to school.

Research and suggestions for future work will arise with the search for autonomy of the teachers who make up the teaching group involved with this theme, in the search for specialization courses, masters and doctorates that involve our object of study of this work, in addition to the possibility between a integration and exchange of information between Chemistry professors who work with the line of research, which addresses our research.

\section{References}

Bottentuit Junior, J. B., \& Coutinho, C. P. (2009) Podcast uma Ferramenta Tecnológica para auxílio ao Ensino de Deficientes Visuais. In VIII LUSOCOM: Comunicação, Espaço Global e Lusofonia.: Universidade Lusófona de Humanidades e Tecnologias. p.2114-2126.

Castells, M. (2003). A Galáxia da Internet. Reflexões sobre a internet, os negócios e a sociedade. Jorge Zahar.

Chalita, G (2001). Educação: a solução está no afeto. (6a. ed.), Gente.

Chiapinotto, D. (2010). Linguagem, educação e TICs. Conjectura, 15(2).

Da Silva, R. E. V. (2009). Informática na Educação e o Ensino de Ciências Naturais: Contribuições para a Educação Ambiental no Contexto Amazônico. 158f. Dissertação (Mestrado Profissional em Ensino de Ciências na Amazônia) - Universidade do Estado do Amazonas, UEA, Manaus.

Dante, H. M. (2004). Sociedade, educação, tecnologia e os usos das TICs nos processos educativos. Trabalho Necessário. Ano2. no 2.

Fofonca, E. (2009) A Prática Comunicacional dos Blogs: Contribuições da Comunicação para a Educação Contemporânea. ANIMUS - Revista Interamericana de Comunicação Midiática. 16 (2).

Freire, P. (1996). Pedagogia da Autonomia: saberes necessários à prática educativa. (19a ed.), Paz e Terra.

Garcia, P. B. (2004). Profissão desejo. Nós da Escola: educação multirio. ano 2 no 18.

Gutiérrez, F. (2003) Dimensão pedagógica das novas tecnologias da comunicação e informação. In: PORTO, Tania M. E. (Org.). Redes em construção: meios de comunicação e práticas educativas. Araraquara: JM Editora, p. 33-40.

Inácio Filho, G. (2004). A monografia na universidade. (7a ed.), Papirus. 
Research, Society and Development, v. 10, n. 11, e297101113459, 2021

(CC BY 4.0) | ISSN 2525-3409 | DOI: http://dx.doi.org/10.33448/rsd-v10i11.13459

Kalhil, J. B. (2003). Estratégia Pedagógica para el desarrollo de habilidades investigativas en la Disciplina Física de Ciências Técnicas. Tese de Doutorado em Ciências Pedagógicas. Universidade de Havana, Havana, Cuba.

Kennisnet Foudation. (2015). Four in balance monitor 2015: use and benefits of ICT in education. Zoetermeer: Kennisnet.

Maia, M. C., \& Meirelles, F. S. (2009). Proceedings of the 3rd ACORN-REDECOM Conference Mexico City Set 04-05rd, 10p,

Malhotra, N. (2001). Pesquisa de Marketing: uma orientação aplicada. Bookman.

Mattar, F. N. (2001). Pesquisa de marketing. Atlas.

Menezes, A. P. S. (2009). História da Física aliada às Tecnologias de Informação e de Comunicação: Organizador Prévio como uma Estratégia facilitadora da Aprendizagem Significativa de Física na Educação Básica. 204f. Dissertação (Mestrado Profissional em Ensino de Ciências na Amazônia) - Universidade do Estado do Amazonas, UEA, Manaus.

Miranda, G. L. (2007). Limites e possibilidades das TIC na educação. Sísifo. Revista de Ciências da Educação, 3, pp. 41-50.

Perrenoud, P. (2000) As dez novas competências para ensinar. Artes Médicas, 2000.

Rabbi, M. A., Neto, D. M. C. (2010). Utilização de tecnologias de informação e Comunicação - TICs no ensino de ciências em espaços não formais. XVIII Simpósio Nacional de Ensino de Física - SNEF 2009 - Formação Continuada de Professores em Serviço: Educação de Qualidade para uma Sociedade da Aprendizagem Vitória, ES. http://www.sbf1.sbfisica.org.br/eventos/snef/xviii/

Santana, R. J. (2009). A importância da formação continuada de professores para a prática da tutoria de química no CESAD/UFS. Anais do II Seminário Educação, Comunicação, Inclusão e Interculturalidade. p.966-977.

Tálamo, M. F. G. M. (2004) A pesquisa: recepção da informação e produção do conhecimento. DataGamaZero, Revista de Ciência da Informação, 5(2).

Tresca, R. P., De Rose JR, D. (2009). Estudo comparativo da motivação intrínseca em escolares praticantes e não praticantes de dança. Dissertação de mestrado, Universidade Católica de Brasília, DF.

Trevisan, P. F. F. (2008). Ensino de Ciências para surdos através de Software Educacional. 118f. Dissertação (Mestrado Profissional em Ensino de Ciências na Amazônia) - Universidade do Estado do Amazonas, UEA, Manaus.

Trivelato, S. L. F. (2003). Um programa de ciências para formação continuada. In Carvalho, A. M. P. de. (Coord.). Formação continuada de professores: uma releitura das áreas de conteúdo. Thomsom, 63-85. 